\title{
A COMPARATIVE STUDY OF THE CONCEPT OF TRADITION BY T. S. ELIOT AND F. R. LEAVIS
}

\author{
Dr. D. P. Deolalkar \\ Associate Professor, \\ Department of English, \\ Govt. Vidarbha Institute of Science and Humanities, \\ Amravati.
}

\begin{abstract}
Tradition is one of the most significant concepts in critical discourses. It is significant because it defines the chronological sequence, peculiar characteristics and tendencies of different periods. And at the same time it addresses the innovation and shifts taken by literary writers, thinkers and critics. Tradition is a comprehensive term that encompasses not only the temporal aspect of literature but also its tendencies and trends. Therefore the study of the concept of tradition becomes imperative to understand literature. The concept of tradition has undergone several temporal and spatial changes in the course of time. The essay 'Tradition and the Individual Talent' was a building block for much Anglo-American criticism. In his essay, Eliot argues that writers must have 'the historical sense' which can be seen as a sense of tradition. It is not the knowledge of specific events in history, but rather an encompassing feeling of past literature which inspires the writer to write originally and with the spirit of the past in mind.

Leavis believed that there were 'great works' of literature, therefore he remains a strong supporter of the existing canon. Leavis's criticism has a sense of the past. It relates historical context to the poem and poet. Historical and social background is not a focus of Leavis's criticism. However, the focus of Leavis's criticism has always been on the text in terms of words and how they relate to one another. In 1948, Leavis has focused his attention on fiction and made his general statements about the English novel in The Great Tradition where he has traced this tradition through Jane Austen, George Eliot, Henry James, and Joseph Conrad. He talks about Seriousness and moral purpose of literature. For him literature is great if it teaches morality.
\end{abstract}

Keywords: History, canon, tradition, Literary History, Past, Present and Morality

The present paper is an attempt to discuss and compare the notion of tradition viewed by T. S. Eliot and F R Leavis. T.S.Eliot and F.R.Leavis are the critics of New Criticism School. They insist on importance of tradition in making of literature as well as to criticise literature. T. S. Eliot, a well-known modern poet-critc puts emphasis on importance of tradition in his critical writings. Tradition, for Eliot, is dynamic process, retaining some traits at the same time changing according to time. Literary historians while writing literary history insist on continuity as well as on shifts in literary production. They try to trace the development and growth of particular genre and style.

The word 'tradition' comes from the Latin word traditio which means "to hand down" or "to hand over." It is used in a number of ways in the English language:

1. A meme; beliefs or customs taught by one generation to the next, often orally. For example, one can speak of the tradition of sending birth announcements.

2. A set of customs or practices. For example, one can speak of Christmas traditions.

3. A broad religious movement made up of religious denominations or church bodies that have a common history, customs, culture, and, to some extent, body of teachings. For example, one can speak of Islam's Sufi tradition or Christianity's Lutheran tradition.

However, on a more basic theoretical level, tradition can be seen as information or composed of information. For that which is brought into the present from the past, in a particular societal context, is information. This is even more fundamental than particular acts or practices even if repeated over a long sequence of time. For such acts or practices, once performed, disappear unless they have been transformed into some manner of communicable information.

Tradition is a multivalent concept. It is contradistinctive term different from convention. There are various shades of the concept tradition.

Wikipedia, an online encyclopaedia, defines tradition as:

a) Custom opinion or belief handed down to posterity orally or by practice.

b) This process of handing down. 


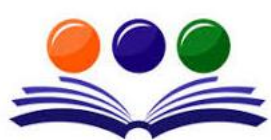

GRAND ACADEMIC PORTAL RESEARCH JOURNALS

A GLOBAL JOURNAL OF SOCIAL SCIENCES

( ISSN - 2581-5830 )

Impact Factor - SJIF - 4.998, IIFS - 4.375

Globally peer-reviewed and open access journal.

Tradition is a practice, custom or story that is memorized and passed down from generation to generation, originally without the need for a writing system. Tools to aid this process include poetic devices such as rhyme and alliteration. The stories thus preserved are also referred to as tradition or as part of an oral tradition.

The New Oxford Illustrated English Dictionary defines tradition as-

The action of transmitting or "handing down", or fact of being handed down, from one to another, or from generation to generation; transmission of statements, beliefs, rules, customs, or the like.(1)

All dictionary entries related to tradition hint at continuity of past. The term 'tradition' is used almost in all branches of knowledge. The folk art and critics of folk art are solely dependent on tradition for expression as well as for explanation. Folk art itself is tradition

Henry Glassie defines tradition saying,

It is a rich word, lacking an exact synonym, naming the process by which individuals simultaneously connect to the past and the present while building the future. So tradition can label the collective resource, essential to all creativity, and in adjective form it can qualify the products of people who keep faith with their dead teachers and their live companions while shaping their actions responsibly. Traditions detractors associate it with stasis and contrast it with a change, but it is rooted in volition and it flowers in variation and innovation. (2)

The traditional perception of the concept of tradition implies contiuity but Eliot conceives it flexible and not rigid so that changes are assimilated

Tradition is a constant process across time and in time, linking past with present, thus ensuring continuity. It is also dynamic and ever-changing as culture and societal needs alter. (3)

Some critics strongly found it difficult to define the concept of tradition. Handler and Linniken say:

Tradition cannot be defined in terms of boundedness, givenness, or essence. Rather, tradition refers to an interpretive process that embodies both continuity and discontinuity. . . . Thus we can no longer speak of tradition in terms of the approximate identity of some objective thing that changes while remaining the same. Instead, we must understand tradition as a symbolic process that both presupposes past symbolisms and creatively reinterprets them. In other words, tradition is not a bounded entity made up of bounded constituent parts, but a process of interpretation, attributing meaning in the present through making reference to the past. . . . This understanding of tradition implies that society, commonly perceived as the largest unit of social reality, is, like tradition, a meaningful process rather a bounded object. Social identity is always formulated in interaction with others, and depends upon evolving distinctions between categories that are symbolically constituted.... Tradition is always defined in the present ... [and] never exists apart from our interpretations of them. (4)

This is clear enough in the field of art. Tradition conceived as the handing down of set formulas and the enforced and servile imitation of models learned in the classroom would lead to sterility.

Tradition explains the ways that people rely on one another, with reference to past, for their wisdom, their expression, and their identity. Tradition in most dictionaries is defined as the 'handing down' of lore from generation to generation, especially by oral means. As one goes down the list, more authority is ascribed to tradition. The suggestion of reverence due tradition means that people follow it, willingly or not, and may define it through its presence. Tradition in its most authoritarian sense is a natural way of doing things which goes unchallenged because it is a basis of social life.

To claim tradition, after all, is to bring into play the force, and guilt, of countless generations of ancestors, and perhaps the gaze of present-day neighbours. In political usage, it allows for a natural state; it refers to the givens of public practice, and suggests, problematically, that the longstanding character of a practice is justification for its continuation. For religion, to follow tradition may be construed as keeping the faith; to break it at the risk of apostasy. Hence, a vibrant legacy of writing on tradition exists from the view of how religion draws its meaning from continuities of shared ritual and belief and how individual expressions of art and literature respond to socially inherited aesthetics, symbols, and themes. That is not to say that attempts to clinically objectify tradition do not exist, particularly in folkloristics which above all other disciplines have claimed it for its sense of being. Tradition can be calculatedly viewed as a biological specimen and given the look of a genealogical chart. It may be solidly recorded as a series of motions and minutely analyzed frame by frame. Traditions can be alternatively "collected" as empirical evidence of everyday practice or in the singular described as some conceptual, almost mystical whole, often outside the awareness of individuals. In both directions, scientific and humanistic, the problem of tradition questions the sources from which people draw the basis of actions and attitudes.

It is necessary to look to tradition not as a mere storehouse of the past customs, but as the dynamic process of human decision-making and commitment in which our life finds both its challenge, its bearings and its hope. Such a search begins in the moral order, but points beyond it. According to Kant, the moral tradition of a people can be an essential resource and it holds great promise for building the future, provided it can be effectively accessed and creatively drawn upon.

Literacy criticism and literary theory have shown much more interest in the concept of tradition. The notion of tradition changes its meaning and significance from age to age. This term has been used in almost all the branches of knowledge with various connections viz religion, philosophy, sociology, history, anthropology, archeology, literature and so on. Many critics and scholars tried best each to define tradition but it is too 


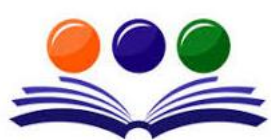

GRAND ACADEMIC PORTAL RESEARCH JOURNALS

A GLOBAL JOURNAL OF SOCIAL SCIENCES

( ISSN - 2581-5830 )

Impact Factor - SJIF - 4.998, IIFS - 4.375

Globally peer-reviewed and open access journal.

flexible to be formulated in an acceptable definition. In archaeology a tradition is a set of cultures or industries which appear to develop on from one another over a period of time.

For many, tradition is simply a collection of time honored customs accepted not on critical grounds but merely because things have always been so, because it has always been dome. In such case tradition is favored because it prevents charge. We speak of national or regional traditions. In these examples the word 'tradition' connotes something more than mere conservatism something deeper involved namely the continual presence of a spirit and of a moral attitude the continuity of an ethos.Tradition is not just a conservative force, but rather a principle that ensures the continuity and identity of the same attitude through successive generations.

A Sociologist defines tradition as:

"Tradition, in the true sense of the word, implies a spontaneous assimilation of the past in the understanding the present without a break in the continuity of a society's life, and without considering the past as outmoted." (5)

In it different forms, tradition is like the conscience of a group, or the principle of identity that links one generation with another, it enables them to remain the same human race and the same peoples as they go forward throughout history, which transforms all things. If tradition is a continuity that goes beyond conservatism, it is also a movement and progress that is not simply repletion of the past. Tradition is memory and memory enriches experience. If we remember nothing it would be impossible to advance; the same would be true if we were bound to a slavish imitation of the past. True tradition is not servility but fidelity.

Tradition always implies learning from others but the academic type of docility and imitation is not the only one possible, there is also the will to learn from the experience of those who have studied and created before us, the aim of lesson is to receive the vitality of their inspiration and to continue their creative work in its original spirit, which thus in a new generation is born again with the freedom the youthfulness and the promise that it originally possessed.

We have various types of tradition like scientific tradition, artistic tradition, sociological tradition, moral tradition, Christian tradition and so on.

Encyclopedia Britannica defines tradition as follows-

The aggregate of customs, beliefs and practices that give continuity to a culture, civilization or social group and thus shape its views; taken in this sense, laws and institutions are also part of tradition. In certain religions, tradition signifies essential doctrines or tenets that are not explicitly set down in sacred scriptures but are accepted as so orthodox and authoritative that they have equal authority with secret writing and are sometimes used to interpret them. (6)

As a dynamic process, tradition flows from and shapes individual lives, while shaping and resonating with larger patterns of worldview and culture. People's creations draw upon unique combinations of community life and personal inspiration. Tradition flows into and from this process of convergence.

Tradition is arguably both more abstract and more concrete than the ways anthropologist and historians use the term culture. Tradition consists of an Individual and collective interpretive relationships to the past, present and future. Tradition is an analytical category. Tradition itself is a modern concept that emerges out of the Enlightenment movement. Tradition is not nostalgia because nostalgia is a kind of impossible wish, a desire for the pastness of the past. Tradition is an interpretive model of the past but located in the present.

"Tradition references the past, its relationship to the past is not natural but discursive and embodies continuities as well as discontinuities." (07)

The major works of literature form between them an ideal order, occasionally redefined by the entry of a new masterpiece. The existing classics within the cramped space of the tradition politely reshuffle their positions to make room for a newcomer, and look different in the light of it. But since this newcomer must somehow have been in principle included in the tradition all along to have gained admission at all, its entry serves to confirm that traditions central values are retained. F.R.Leavis in his book The Great Tradition speaks about tradition in which; he includes novelists of his 'choice' to show the bearer and carrier of tradition.

F.R.Leavis, who insists on 'Great tradition', denounces Milton and Romantic poets as literary artists. He says, 'since Donne, there is no poet we need bother about except Hopkins and Eliot'. Because other poets do not qualify the 'Screening Test' set by F.R.Leavis on his account of 'English Tradition'. In the same way he chose the novelists who came up to his 'expectations' and they are Jane Austen, George Eliot, Henry James and Joseph Conrad and he adds saying that 'there are no novelists in English worth reading. The 'chosen few' by Leavis are significant because they are successful to promote human awareness and awareness of the possibilities of life according to him. Later on, he included D.H.Lawrence, and wrote a separate book on him. For F.R.Leavis-

'Tradition is a term with many forces-and often very little at all.....To distinguish the major novelists in the spirit proposed is to form a more useful idea of tradition. It is in terms of the major novelists, those significant in the way suggested, that tradition, in any serious sense, has its significance.' (08)

F.R.Leavis celebrates 'Individual talent' of Jane Austen as novelist to relate her to tradition in following words: 


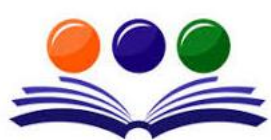

GRAND ACADEMIC PORTAL RESEARCH JOURNALS

A GLOBAL JOURNAL OF SOCIAL SCIENCES

( ISSN - 2581-5830 )

Impact Factor - SJIF - 4.998, IIFS - 4.375

Globally peer-reviewed and open access journal.

'Her work, like the work of all great creative writers, gives a meaning to the past.... Jane Austen, in fact, is the inaugurator of the great tradition of the English novel-and by 'great tradition' I mean the tradition to which w3hat is great in English fiction belongs.' (09)

Novel as a genre in English Literature is a very late phenomenon (of the seventeenth century to be particular). In that sense a very modern yet Leavis formulates its tradition to deny other artists their due place. New Historicists like Greenblatt rejects this limited view of tradition and encompasses not only other novels but even non-literary texts. F.R.Leavis includes Conrad in his 'List' because Conrad is 'significantly' in 'traditionin and of it', though his first language was Polish. Conrad becomes a 'British Master Mariner'. The Merchant service is for him both a spiritual fact and a spiritual symbol. So he 'unquestionably' becomes a 'constitutive part of the tradition'.

According to Leavis, what modern society mostly suffers from is the loss of tradition. Leavis saw tradition as inherited habits and established valuations, making it almost synonymous with language:

'It is the upshot or precipitate of immemorial human living, and embodies values, distinctions, identifications, conclusions, Promptings, catographical hints and tested potentialities' (10)

From this it is clear that for Leavis, tradition is not primarily a collection of 'great works' but the product of a creative collaboration by everyone in the community. Without the intellectual, moral and spiritual resources of tradition, one is unable to negotiate new experiences and as society continues to develop, one faces further the danger of losing sight of the human need to feel that life is significant.

It is this conception of tradition as a form of diffused creativity that sustains cultural continuity which Leavis defended in his notorious response to Sir Charles Show's Rede Lecture, 'The Scientific Revolution and the Two Cultures'.(1959) Leavis believed that without the precedent of the past, one has no means of assessing what is truly significant in the present. The central difference between Leavis and Theory is that for Leavis process of valuation is important whereas for the theorists plurality of meaning is important.

For Leavis, there is one area, where we can continue the work of tradition, where we can consider the relationship between heritage and here and now, and that is the study of Literature. The critic maintains the 'Living Principle'- Leavis's other term for tradition-by making the works of the past live in the present, and by identifying the significant new life in contemporary literature. Leavis believed that one's sense of a literary work is bound up with one's consciousness of tradition:

Leavis solely did not agree with Wordsworth's definition of poetry 'as an expression of personality' but very close to T.S.Eliot's notion of impersonality. As a true artist, the creative individual "knows he does not belong to himself, he serves something (tradition) that is quite other to his selfhood, which is blind and blank to it". (11)

The purpose of evaluating literature is to keep alive the tradition of the human world, not by admiring its achievements, but by bringing its values, purpose and significance to bear on the present. F.R.Leavis was interested in moral preoccupations in his criticism and has developed his own theory which is very difficult to summarize. Even he himself never charted it out but often used the terminology like life, sensibility, vision, charm, moral truth, moral intention, morality, etc.

'The work of any poet trusts by reason of its connection with past work both in continuation and in divergence, and what we call his originality is simply his special relation to tradition.' (12)

T.S.Eliot reminds how each poet's relation to tradition changes tradition itself, so that the history of literature is never quiet for long and is never merely an additive kind of growth. He views literature as a simultaneous order as well as literature as individual works arranged in a chronological order as integral components of a historical process.

Eliot's idea of specifically English literary tradition also signifies a resistance to all those impulses in himself that he regarded as 'romantic'; the inchoate, the subconscious, the ungovernable. The emphasis of Eliot is on unity and wholeness. In fact, Eliot's view of history is basically romantic in its nostalgia for a lost golden age.

Tradition heightens self-consciousness about the politics of the production of knowledge and one's own narrative relationships to specific traditions. T.S. Eliot's cardinal essay 'Tradition and the Individual Talent' -is a major landmark in the development of modern literary criticism. This essay has a strong claim to be seen as the most resonant and widely discussed critical statement of twentieth-century Anglo-American literary theory. It has certainly been a fountainhead and indispensable reference point for subsequent examinations of cultural and artistic traditions. In the same way F R Leavis' The Great Tradition insists on the role of literature in society.

\section{REFERENCES}

[1] The New Oxford Illustrated Dictionary, Vol. II Oxford: Oxford University Press. 1962, Reprinted 1981 by Bay Books. p. 1772.

[2] Henry, Glassie Turkish Traditional Art Today Bloomington: IU Press, 1993. p.x

[3] Brown, Mary Ellen. Burns and Tradition Champaign: University of Illinois Press, 1984.p. xii 


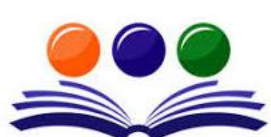

GRAND ACADEMIC PORTAL RESEARCH JOURNALS

\section{A GLOBAL JOURNAL OF SOCIAL SCIENCES}

( ISSN - 2581-5830 )

Impact Factor - SJIF - 4.998, IIFS - 4.375

Globally peer-reviewed and open access journal.

[4] Handler, Richard \& Jocelyn Linnekin, 'Tradition, Genuine or Spurious' in Journal of American Folklore, 1984. p. 120

[5] Dufrenne, M. Note sur la tradition' Cahiers Internat.de Sociologie 1947. p.167

[6] Encyclopedia 'Britannica Miscropaedia Volume No. X. p.84

[7] Handler, Richard \& Jocelyn Linnekin, 'Tradition, Genuine or Spurious' in Journal of American Folklore 1984. p. 120

[8] Leavis, F.R The Great Tradition; New York, Penguin Books, 1948, p.10

[9] Leavis, F.R The Great Tradition New York: Penguin Books, 1948.p.11

[10]Leavis, F.R. The Living Principle: 'English' as a Discipline of Thought London; Chatto and Windus, 1975. P.44.

[11]Leavis, F.R. Nor Shall my Sword: Discourse on Pluralism, compassion and social Hope. London: Chatto \& Windus, 1972. P. 172.

[12] Trilling, Lionel The Liberal Imagination New York: Doubleday \& Co. Luc, 1957. P. 179 